Conflict of Interest: The authors of this paper have no conflicts of interest, including specific financial interests, relationships, and/or affiliations relevant to the subject matter or materials included.

\section{References}

1. Hall GW. Kasabach-Merritt syndrome: pathogenesis and management. $\mathrm{Br} J$ Haematol 2001;112:851-862.

2. Aslan $A$, Vilsendorf $A M$, Kleine $M$, Bredt $M$, Bektas H. Adult Kasabach-Merritt syndrome due to hepatic giant hemangioma. Case Rep Gastroenterol 2009;3:306-312.

3. Liu X, Yang Z, Tan H, Xu L, Sun Y, Si S, Liu L, Zhou W, Huang J. Giant liver hemangioma with adult Kasabach-Merritt syndrome: case report and literature review. Medicine (Baltimore) 2017;96:e7688.

4. Wu KL, Liao CY, Chang CK, Ho SY, Tyan YS, Huang YC. A huge subcutaneous hematoma in an adult with Kasabach-Merritt syndrome. Am J Case Rep 2017;18:682-686.

5. Oak CY, Jun $\mathrm{CH}$, Cho EA, Lee DH, Cho SB, Park CH, Joo YE, Kim HS, Rew JS, Choi SK. Hepatic hemangioma with Kasabach-Merritt syndrome in an adult patient. Korean J Gastroenterol 2016;67:220-223.

\title{
Spurious Thrombocytosis in the Setting of Hemolytic Anemia and Microcytosis Secondary to Extensive Burn Injury
}

\section{Yaygın Yanık Yaralanmasına Sekonder Gelișen Hemolitik Anemi ve Mikrositoz Zemininde Yalancı Trombositoz}

\author{
(D) Mohammad Faizan Zahid ${ }^{1}$, (D) Mohamed S. Alsammak ${ }^{2}$ \\ ${ }^{1}$ Temple University Hospital, Clinic of Internal Medicine, Philadelphia, Pennsylvania, USA \\ ${ }^{2}$ Temple University Hospital, Clinic of Pathology and Laboratory Medicine, Philadelphia, Pennsylvania, USA
}

To the Editor,

A 57-year-old man was brought to our emergency department from a house fire. On physical examination, he was nonresponsive, hypotensive, and tachycardic with full-thickness skin burns covering the entirety of the body except the lower back ( $>98 \%$ of his body surface area). He was intubated and aggressively resuscitated with IV fluids and multiple pressors for circulatory support.

A complete blood count $(\mathrm{CBC})$ showed normal hemoglobin $(14.5 \mathrm{~g} / \mathrm{dL})$ with leukocytosis $\left(23.6 \times 10^{9} / \mathrm{L}\right)$ and thrombocytosis $\left(979 \times 10^{9} / \mathrm{L}\right)$. Repeat $\mathrm{CBCs}$ also showed thrombocytosis $\left(815 \times 10^{9} / \mathrm{L}\right.$ and $\left.1121 \times 10^{9} / \mathrm{L}\right)$. Microscopic examination of the peripheral blood smear showed widespread red blood cell (RBC) fragmentation, budding, spherocytes, and microspherocytes (Figure 1). Manual platelet count estimates on the peripheral blood smear demonstrated a count of $173 \times 10^{9} / \mathrm{L}$. The patient remained in intractable hypotension and eventually went into cardiac arrest.

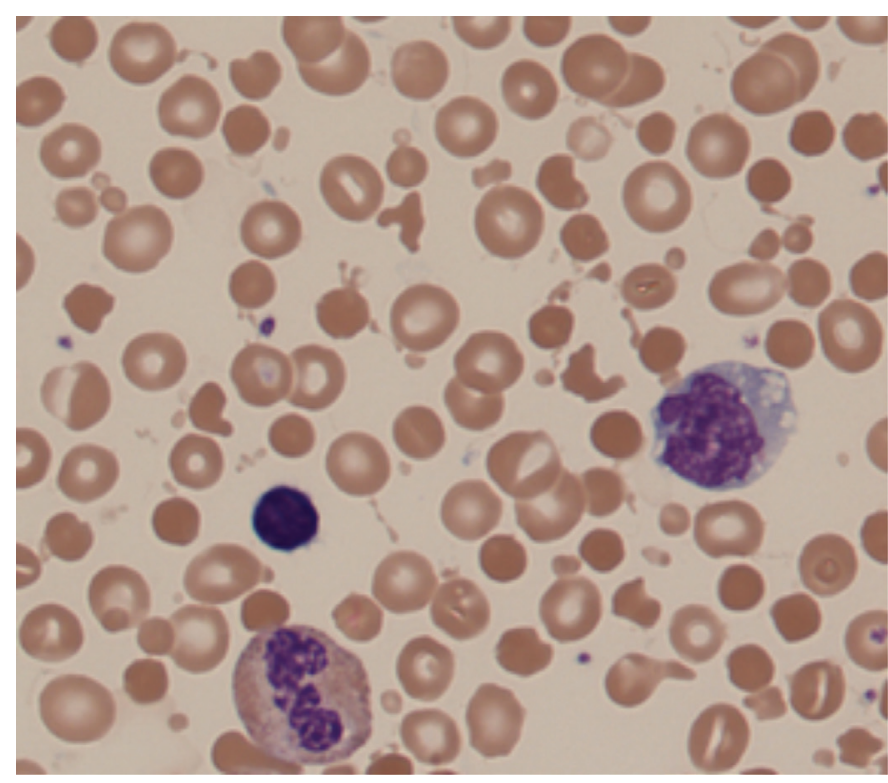

Figure 1. Widespread red blood cell fragmentation, budding, spherocytes, and microspherocytes were revealed by microscopic examination. 
The aforementioned findings are seen in patients with severe burns due to direct thermal injury of RBCs circulating through the skin. Exposure to extreme heat leads to the denaturation of RBC membrane proteins, which results in hemolysis, RBC fragmentation, and vesiculation [1]. The loss of cell membrane causes the RBCs to lose their biconcavity and assume the shape of spherocytes and microspherocytes [1]. These RBC fragments and microspherocytes persist in the peripheral circulation for several days until completely removed from circulation by the reticuloendothelial system in the spleen. They are counted as platelets by aperture-based automated analyzers due to their size, leading to falsely elevated platelet counts in cases of acute burns $[1,2]$. Although reactive thrombocytosis can be seen in acute injury as recently reported by Sapanara et al. [2] in a similar burn case of a 48-year-old woman, such instances should always prompt a microscopic examination of the peripheral smear to confirm if in fact the platelet count is elevated. A manual count of platelets on peripheral smear from that patient (as in our case) revealed a normal platelet count. Such examples emphasize the importance of correlating the peripheral smear with automated $\mathrm{CBC}$ results.
Keywords: Spurious, Thrombocytosis, Burn, Platelets, Microcytosis

Anahtar Sözcükler: Yalancı, Trombositoz, Yanıklar, Trombositler, Mikrositoz

Contributors' Statement: M.F.Z. and M.S.A. both reviewed the peripheral smear and took the image. M.F.Z. wrote the first draft of the manuscript and M.S.A. revised it for intellectual content. Both authors approved the final version of the manuscript being submitted.

Conflict of Interest: The authors of this paper have no conflicts of interest, including specific financial interests, relationships, and/or affiliations relevant to the subject matter or materials included.

\section{References}

1. Lawrence $C, A$ tac $B$. Hematologic changes in massive burn injury. Crit Care Med 1992;20:1284-1288.

2. Sapanara NL, Tanev SS, Swami V. Spurious thrombocytosis in a burn patient. Lab Med 2015;35:98-100.

๑Copyright 2018 by Turkish Society of Hematology

Turkish Journal of Hematology, Published by Galenos Publishing House

\title{
A Rare Cause of Paraplegia: Myeloid Sarcoma
}

\author{
Nadir Bir Parapleji Nedeni: Myeloid Sarkom
}

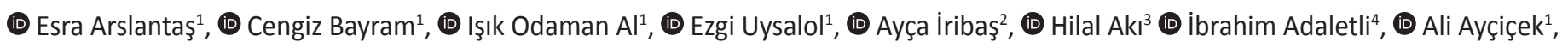
(1) Nihal Özdemir ${ }^{1}$

${ }^{1}$ University of Health Sciences, Kanuni Sultan Süleyman Traning and Research Hospital, Clinic of Pediatric Hematology and Oncology, Istanbul, Turkey

${ }^{2}$ istanbul University Institute of Oncology, Department of Radiation Oncology, Istanbul, Turkey

${ }^{3}$ istanbul University Cerrahpaşa Faculty of Medicine, Department of Pathology, İstanbul, Turkey

${ }^{4}$ istanbul University Cerrahpaşa Faculty of Medicine, Department of Radiology, Istanbul, Turkey

To the Editor,

Myeloid sarcoma (MS), also known as granulocytic sarcoma or chloroma, is a rare extramedullary tumor consisting of myeloblasts or immature myeloid cells that disrupt the normal architecture of the involved tissue and typically occurs concurrently with acute myeloid leukemia (AML) [1,2]. It can also occur in association with accelerated-phase chronic myeloid leukemia or myelodysplastic syndrome; as an extramedullary relapse of AML, including in the post-bone marrow transplant setting; and occasionally as the first presenting manifestation, even before bone marrow involvement $[3,4]$. Bone, periosteum, skin, orbit, lymph nodes, the gastrointestinal tract, and the central nervous system are the most commonly involved sites in patients presenting with MS; however, skin and orbital localizations are the most often reported sites in children [4]. Here we present a 4-year-old male patient who was referred to the pediatric hematology oncology clinic due to a thoracolumbar mass and subsequently diagnosed with MS. 